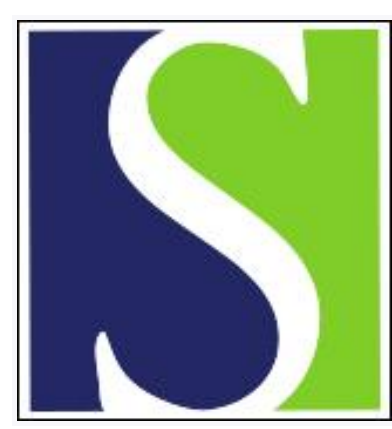

Scand J Work Environ Health 2000;26(6):476-481

https://doi.org/10.5271/sjweh.571

Issue date: Dec 2000

\section{Bladder cancer in the textile industry}

by Serra C, Bonfill X, Sunyer J, Urrutia G, Turuguet D, Bastús R, Roqué M, 't Mannetje A, Kogevinas M, Working Group on the Study of Bladder Cancer in the County of Vallès Occidental

Key terms: case-referent study; epidemiology; occupation; population-based study; risk factor

This article in PubMed: www.ncbi.nlm.nih.gov/pubmed/11201394

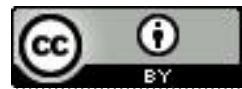




\title{
Bladder cancer in the textile industry
}

\author{
by Consol Serra, MD, ${ }^{1,2}$ Xavier Bonfill, PhD, ${ }^{1}$ Jordi Sunyer, PhD, ${ }^{3}$ Gerard Urrutia, MD, ${ }^{1}$ Domènech Turu- \\ guet, MSc, ${ }^{4}$ Romà Bastús, MD, ${ }^{5}$ Marta Roqué, BSc, ${ }^{1}$ Andrea 't Mannetje, MSc, ${ }^{3}$ Manolis Kogevinas, \\ $P h D, 3$ Working Group on the Study of Bladder Cancer in the County of Vallès Occidental ${ }^{6}$
}

\begin{abstract}
Serra C, Bonfill X, Sunyer J, Urrutia G, Turuguet D, Bastús R, Roqué M, 't Mannetje A, Kogevinas M, Working Group on the Study of Bladder Cancer in the County of Vallès Occidental. Bladder cancer in the textile industry. Scand J Work Environ Health 2000;26(6):476-481.
\end{abstract}

\begin{abstract}
Objectives This study examined the occupations and industries at high risk for bladder cancer in an area where the textile industry is plentiful and the incidence of the disease is very high.

Methods A case-referent study concerning 218 incident bladder cancer cases diagnosed during 1993-1995 in the county of Vallès Occidental, Barcelona, was carried out. A reference group $(\mathrm{N}=344)$ was selected from municipal lists matched to the cases by age, gender, and area of residence. All the subjects were personally interviewed, and a complete occupational history was abstracted together with other sociodemographic and life-style factors. All odds ratios (OR) and $95 \%$ confidence intervals $(95 \% \mathrm{CI}$ ) were adjusted for age, gender, and smoking.

Resulls No overall excess risk was found for ever having worked in the textile industry (OR $1.13,95 \% \mathrm{CI} 0.79-$ 1.63) nor for specific sectors of this industry (ie cotton, wool, silk). An excess risk was observed for spinners and winders employed for more than 20 years (OR 3.28, 95\% CI 1.08-9.97) and for machine setters employed between 1960 and 1974 (OR 4.26, 95\% CI 1.09-16.7).

Conclusions The results of this study do not support the findings of some earlier studies for an increased bladder cancer risk in the textile industry. However, some elevated risks were observed among the workers with the highest exposures.
\end{abstract}

Key ferms case-referent study, epidemiology, occupation, population-based, risk factors.

Bladder cancer is common in industrialized countries (1, 2). The main identified etiologic factors are tobacco smoking and occupation (3-5). It has been estimated that between $1 \%$ and $20 \%$ of bladder cancer cases can be attributed to occupation $(6-8)$.
Several studies have found an association between bladder cancer and employment in the textile industry $(9-15)$. For specific textile occupations and activities, such as dyeing and printing, the association is well established, and exposure to napthylamines, known carcin-

1 Centre for Studies, Programs and Services on Health Care — Fundació Parc Taulí. Sabadell (Barcelona), Spain.

2 Universitat Pompeu Fabra, Barcelona, Spain.

3 Municipal Institute of Medical Investigation, Barcelona, Spain.

4 Industrial Hygienist, independent, Barcelona, Spain.

$5 \quad$ Hospital Mútua de Terrassa, Terrassa (Barcelona), Spain.

6 The members of the Working Group on the Study of Bladder Cancer in the county of Vallès Occidental are J Prats, D García, J Prera, C Abad, M Nogué, A Cabezuelo, Consorci Hospitalari del Parc Taulí (Sabadell); JM Caballero, J Ristol, Hospital Mútua de Terrassa (Terrassa); M Céspedes, I Roig, C Sevillano, A Tuca, Consorci Sanitari de Terrassa (Terrassa); J Palou, JA Muñoz, Fundació Puigvert (Barcelona); M Becerra, A Fernández, E Maldonado, Quinta de Salut l'Aliança de Sabadell (Sabadell); R Vergés, JM Casanellas, Hospital General de la Vall d'Hebron (Barcelona); G Martí, JM Banús, Hospital de Barcelona (Barcelona); J Ferré, JL Balañà, Hospital General de Catalunya (Sant Cugat del Vallès); JM Mallafré, R Alvarez, A Conesa, Hospital Clínic i Provincial (Barcelona); P Fernández, J Ávila, Hospital del Sagrat Cor (Barcelona); B Quintanilla, Clínica Quirón (Barcelona); M Mando, Hospital de Mollet (Mollet); JJ Ballesteros, Hospital de l'Esperança (Barcelona); MA Várez, Policlínica Plató (Barcelona); J Ribes, Hospital Duran i Reynals/ Bellvitge (L'Hospitalet de Llobregat).

Reprint requests to: Dr Consol Serra, CEPSS - Centre for Studies, Programmes and Services on Health Care, Institut Universitari Fundació Parc Taulí, Parc Taulí, s/n, 08208 — Sabadell (Barcelona), Spain. [E-mail: cserra@cspt.es] 
ogens since the first half of this century $(16,17)$, has been identified. For other occupations, available data are nonconclusive (9-22) and thus deserve further attention (23). One of the limitations of most community-based studies conducted so far is that the prevalence of exposure in the textile industry has been relatively low, and therefore no detailed analysis of occupations and processes within this industry has been possible.

In Spain, incidence and mortality from bladder cancer are high, and increasing rates have been observed for several decades $(24,25)$. The county of Vallès Occidental is a highly industrialized and urbanized area of about 600000 inhabitants in the province of Barcelona. Recent data show that the incidence of bladder cancer in this county (44.1 per 100000 men) is among the highest reported for men (26). Its industrial frame is mainly manufacturing. The textile industry has been very prevalent, employing more than $40 \%$ of the population ever employed in this industry, and it mainly concentrates on wool and cotton products. A population-based case-referent study was conducted with the objective of investigating the risk of bladder cancer in more detail in the textile industry.

\section{Subjects and methods}

The study base was the county of Vallès Occidental. The cases were defined as all persons living in that area with a histopathologically confirmed first diagnosis of malignant tumor of the urinary bladder, coded as ICD-188 in the 9th revision of the International Classification of Diseases, between 1 October 1993 and 31 May 1995. They were selected through the hospitals of the county and through 11 other hospitals, mainly from the city of Barcelona, where some cases of the county were diagnosed or treated.

The reference group was a population-based sample of living persons without any kind of known benign or malignant tumor of the urinary tract, and their area of residence belonged within the county of Vallès Occidental at the time of selection. Two referents per case were randomly selected using municipal-based census lists. The exclusion criteria were the same as for the cases. The referents were individually matched to the case series by gender, age (5-year groups) and municipal area of residence.

An active search of cases was carried out by establishing specific strategies of detection for each hospital. An exhaustive detection was ensured by enlisting the participation of 1 person from the urology, oncology, pathology or admissions department in each hospital. A co-ordinator supervised complete and efficient case detection in all the centers. Completeness was periodically validated from the information systems (admission lists, pathology records, etc) of all the centers. For the selection of referents, a participant was also assigned in each town hall, and a random selection strategy was established for each one. Once a case was detected and included in the study, 2 referents were randomly selected from the census list, according to the gender and age of the case.

The cases and referents were interviewed by means of a standardized questionnaire (27). It included demographic data, complete occupational history, lifetime tobacco consumption, history of urinary tract infections, and coffee consumption. Only jobs held for at least 6 months were included. For each job, the year the job began and finished, the subject's occupation, a description of tasks performed, the type of activity of the company, its size, name and address, and the main products manufactured or services provided were recorded. To reinforce the recall of suspected occupations, specific questions were included, and exposure in several occupations and sectors within the textile industry was also specifically asked. Interviews were carried out by 3 trained interviewers either at home, at an office of the coordinating center, or during admission to a hospital or a visit to an outpatient clinic. Each occupation was coded using the Spanish National Classification of Occupations (CNO, 1979), which is an adaptation of the 1968 version of the International Standard Classification of Occupations (ISCO) of the International Labour Office. The work activities of companies were coded using the Spanish Classification of Economic Activities of 1993. For the textile industry, some other ad-hoc codes were also used for a small fraction of persons when the company had several subtextile activities and the occupation was nonspecific so that a specific activity code could not be assigned (eg, a blue-collar worker in a spinning and weaving factory). Under such circumstances, a code summarizing the combination of different industrial activities within this industry was devised. Codification was carried out by an expert (DT) in hygiene, who was blind as to the casereferent status.

Altogether of 277 cases and 491 referents were detected. Of them, $220(79.4 \%)$ cases and $349(71.1 \%)$ referents were interviewed. Of the 57 cases and 142 referents that could not be interviewed, 11 cases and 68 referents could not be traced, 12 cases and 8 referents had serious difficulties, due to poor health, to respond to the questionnaire, 23 cases and 62 referents refused to participate, 10 cases and 3 referents died before the interview could be carried out, and 1 case and 1 referent could not be interviewed for other reasons. After the interview, 2 other cases were excluded because a previous diagnosis of bladder cancer was determined during the interview or the case did not meet the diagnostic criteria once additional clinical information was available, and 5 
Table 1. Description of the case subjects and the referents.

\begin{tabular}{|c|c|c|c|c|}
\hline & \multicolumn{2}{|c|}{$\begin{array}{l}\text { Subjects } \\
(\mathbb{N}=218)\end{array}$} & \multicolumn{2}{|c|}{$\begin{array}{l}\text { Referents } \\
(N=344)\end{array}$} \\
\hline & N & $\%$ & N & $\%$ \\
\hline \multicolumn{5}{|l|}{ Age (years) } \\
\hline$<35$ & 2 & 0.9 & 6 & 1.8 \\
\hline $36-55$ & 32 & 14.7 & 38 & 11.0 \\
\hline $56-75$ & 134 & 61.5 & 230 & 66.9 \\
\hline$\geq 76$ & 43 & 20.4 & 63 & 18.3 \\
\hline Missing & 7 & 3.2 & 7 & 2.0 \\
\hline \multicolumn{5}{|l|}{ Gender } \\
\hline Male & 196 & 89.9 & 314 & 91.3 \\
\hline Female & 22 & 10.1 & 30 & 8.7 \\
\hline \multicolumn{5}{|l|}{ Marital status } \\
\hline Single & 2 & 0.9 & 13 & 3.8 \\
\hline Married & 183 & 83.9 & 285 & 82.8 \\
\hline Widow & 29 & 13.3 & 37 & 10.8 \\
\hline Divorced & 3 & 1.4 & 6 & 1.7 \\
\hline Missing & 1 & 0.5 & 3 & 0.9 \\
\hline \multicolumn{5}{|l|}{ Educational level } \\
\hline Some primary education & 106 & 48.8 & 156 & 45.7 \\
\hline Elementary education & 77 & 35.5 & 129 & 37.8 \\
\hline High school & 25 & 11.5 & 37 & 10.9 \\
\hline Higher education & 9 & 4.1 & 19 & 5.6 \\
\hline Missing & 1 & 0.5 & 3 & 0.9 \\
\hline \multicolumn{5}{|l|}{ Smoking status } \\
\hline Ever smokeda & 185 & 84.9 & 241 & 70.1 \\
\hline \multicolumn{5}{|l|}{ Pack-years ${ }^{b}$} \\
\hline 0 & 38 & 17.4 & 109 & 31.7 \\
\hline$>0-15$ & 17 & 7.8 & 64 & 18.6 \\
\hline $15-34$ & 56 & 25.7 & 76 & 22.1 \\
\hline $35-54$ & 62 & 28.4 & 57 & 16.6 \\
\hline$\geq 55$ & 45 & 20.6 & 38 & 11.0 \\
\hline
\end{tabular}

any kind of tobacco (cigarettes, cigars, pipe)

t It refers only to ever cigarette smokers; thus 3 case subjects and 5 referents who never smoked cigarettes, but had only other forms of tobacco use (cigars, pipe) were excluded from this analysis. In addition, 2 case subjects and 1 referent who had ever smoked cigarettes but had missing information about the number of smoked cigarettes per day were excluded.

Table 2. Association between the occupational groups in the textile industry and bladder cancer. $(95 \% \mathrm{Cl}=95 \%$ confidence interval)

\begin{tabular}{lcccc}
\hline Occupational group & $\begin{array}{c}\text { Case } \\
\text { subjects }\end{array}$ & $\begin{array}{c}\text { Refer- }^{\mathrm{ents}}{ }^{\mathrm{b}} \\
\text { Never textile (-) }\end{array}$ & $\begin{array}{c}\text { Odds } \\
\text { ratioc }^{c}\end{array}$ & $95 \% \mathrm{Cl}$ \\
$\begin{array}{l}\text { All textile occupations } \\
(75 / 79)\end{array}$ & 75 & 113 & 1.03 & $0.70-1.51$ \\
$\begin{array}{l}\text { Textile workers (75) } \\
\text { Tailors, dressmakers }\end{array}$ & 67 & 106 & 0.99 & $0.67-1.47$ \\
and related workers (79) & 11 & 12 & 1.36 & $0.52-3.56$ \\
$\begin{array}{l}\text { Fiber preparers (751) } \\
\text { Spinners and winders (752) }\end{array}$ & 9 & 24 & 0.57 & $0.25-1.30$ \\
$\begin{array}{l}\text { Machine setters and others } \\
\text { (753/841.50/849.45) }\end{array}$ & 11 & 30 & 0.99 & $0.53-1.87$ \\
$\begin{array}{l}\text { Weavers and knitters } \\
\text { (754/755) }\end{array}$ & 24 & 41 & 0.96 & $0.53-1.76$ \\
$\begin{array}{l}\text { Dyers and finishers (756) } \\
\text { Other textile workers }\end{array}$ & 16 & 30 & 0.81 & $0.41-1.59$ \\
\begin{tabular}{l}
$757 / 758 / 759)$ \\
\hline
\end{tabular} & 6 & 4 & 2.33 & $0.62-8.76$ \\
\hline
\end{tabular}

Code of the CNO-1979 in parentheses.

o The reference group were those who had never had a textile occupation.

- Nonconditional logistic regression, adjusted by tobacco consumption, age and gender. referents were also excluded because they had a current or previous diagnosis of bladder cancer. Finally, 218 cases and 344 referents were included in the analysis. The majority of histological types of cases were transitionalcell carcinomas $(93.6 \%)$. The rest were squamous-cell carcinomas $(0.9 \%)$, adenocarcinomas $(4.1 \%)$, and other types $(1.4 \%)$. All the interviews were complete and were carried out at the person's home for $117(53.7 \%)$ cases and $254(73.8 \%)$ referents. The mean duration of the interview was similar for the cases and referents $(46.7$ versus 44.4 minutes), as was the average number of different jobs ever held ( 3.9 versus 4.6 jobs). The cases and referents were similar regarding age, gender, marital status, and educational level, but smoking was more frequent among the cases than among the reference series and cumulative cigarette consumption was also higher for the cases (table 1).

\section{Analysis}

Odds ratios (OR) and their $95 \%$ confidence intervals $(95 \% \mathrm{CI})$ were calculated. Unconditional logistic regression was used, using the SAS (statistical analysis system) for windows. All the analyses were adjusted for age, gender, and smoking (ever versus never smoker). All the jobs were analyzed according to occupation and industrial activity. For the textile industry analysis, unexposed workers were defined as those who had never had a textile occupation or had never worked in a textile industrial activity.

The following three temporal variables were used in the analysis: (i) the period of work, defining 3 different periods [before 1960, 1960 - 1974, and after 1974, according to big changes that occurred in the textile industry of Catalonia at those times (28) and that could well have affected the work conditions], (ii) duration of exposure ( $<10$ years, $10-19$ years and $\geq 20$ years), and (iii) age at first exposure ( $<50$ years and $\geq 50$ years).

\section{Results}

Table 2 shows the analyses for occupations in the textile and dressmaker sector. A proportion of $30.7 \%$ of the cases and $30.8 \%$ of the referents had ever been textile workers, and $5.0 \%$ and $3.5 \%$, respectively, had ever been tailors or dressmakers. The prevalence of specific textile occupations among the referents was high, for example, $7 \%$ for fiber preparers and $11.3 \%$ for spinners and winders. There was no association observed for most occupations, apart from machine setters and other textile workers who had a nonstatistically significant increased risk.

Table 3 shows the analysis for industrial activities for the textile and dressmaker industries. The prevalence of 
the textile industry in the sample was $42.2 \%$ among the cases and $39.2 \%$ among the referents, and for the clothing industry the corresponding figure was $3.2 \%$ for both the cases and referents. For the 3 main sectors of the textile industry (preparing fibers and spinning, weaving, dyeing and finishing) the prevalences ranged between $13 \%$ and $17 \%$ among the reference series. No increased risks were found for the textile industry, although a nonstatistically significant increased risk was observed for the sector of preparing fibers and spinning, involving either cotton or wool materials. Elevated risks were also found for the cotton sector on the whole and for its weaving section, but none of them reached statistical significance.

A statistically significant increased risk was observed for spinners and winders with a duration of $>20$ years (OR 3.28, 95\% CI 1.08-9.97) and for persons exposed in the preparation of fibers and spinning before 1960 (OR $1.82,95 \%$ CI $1.07-3.10$ ). An increasing trend with duration and period of exposure was suggested for machine setters, and a statistically significant increased risk was found for those employed between 1960 and 1974 (OR $4.26,95 \%$ CI $1.09-16.7)$.

For those younger than 50 years of age and those older than 50 years, we compared the risk for textile occupations and main industrial activities for those first employed in each occupation. Although none of the risks were statistically significant, they tended to be higher for those who started at a younger age.

Finally, compared to never smokers, and after adjustment for age and gender, ever smokers showed an elevated risk of bladder cancer (OR 4.31, 95\% CI 2.38-7.79).

\section{Discussion}

Several studies have found an association between the textile industry and bladder cancer, particularly among weavers $(9,12,18)$. The risk of bladder cancer associated with dyeing was established several decades ago, and aromatic amines have been identified as carcinogens for these workers. The results of the present study showed only a small elevated risk. This finding can be explained by the types of textile exposures found in Vallès Occidental, in comparison with other areas, and also by the improvements that have been made in work conditions across time. The county concentrates mainly on woolbased products, and the dyeing of cotton products is rather uncommon. A study carried out in a nearby area (12) found an increased risk of bladder cancer in association with dyeing and weaving. The textile industry in that area, however, mostly involved cotton products, and the dyeing of such cotton goods was very common. Other
Table 3. Association between textile industrial activities and bladder cancer. $(95 \% \mathrm{Cl}=95 \%$ confidence interval)

\begin{tabular}{|c|c|c|c|c|}
\hline $\begin{array}{l}\text { Group of industrial } \\
\text { activity }^{3}\end{array}$ & $\begin{array}{l}\text { Case } \\
\text { subjects }\end{array}$ & $\begin{array}{l}\text { Refer- } \\
\text { ents }\end{array}$ & $\begin{array}{l}\text { Odds } \\
\text { ratioc }\end{array}$ & $95 \% \mathrm{Cl}$ \\
\hline Never textile industry $(-)$ & 117 & 199 & 1 & \\
\hline All textiles $(17 / 18)$ & 101 & 145 & 1.13 & $0.79-1.63$ \\
\hline Textile (17) & 92 & 135 & 1.14 & $0.78-1.64$ \\
\hline Made-up of textile goods (18) & 8) 7 & 11 & 0.86 & $0.28-2.69$ \\
\hline $\begin{array}{l}\text { Preparing fibers and } \\
\text { spinning }(17.1)\end{array}$ & 46 & 59 & 1.41 & $0.88-2.28$ \\
\hline Weaving $\left(17.2^{\circ}\right)$ & 28 & 49 & 0.95 & $0.54-1.66$ \\
\hline Dyeing and finishing $\left(17.3^{i}\right)$ & 27 & 44 & 0.98 & $0.56-1.71$ \\
\hline Cotton $\left(17.110 / 17.210^{d}\right)$ & 22 & 26 & 1.36 & $0.71-2.60$ \\
\hline Wool (17.120/17.130d) & 48 & 78 & 1.11 & $0.71-1.74$ \\
\hline Silk $(17.150)$ & 7 & 9 & 0.96 & $0.29-3.14$ \\
\hline Knitting mills (17.6) & 3 & 7 & 0.52 & $0.10-2.78$ \\
\hline Others $(17.160 / 17.170)$ & 3 & 6 & 0.53 & $0.10-2.83$ \\
\hline $\begin{array}{l}\text { Cotton preparing and } \\
\text { spinning }\left(17.110^{d}\right)\end{array}$ & 13 & 15 & 1.29 & $0.57-2.93$ \\
\hline Cotton weaving $\left(17.210^{d}\right)$ & 12 & 14 & 1.45 & $0.62-3.40$ \\
\hline $\begin{array}{l}\text { Cotton dyeing and } \\
\text { finishing }\left(17.113^{d}\right)\end{array}$ & 1 & 2 & 0.70 & $0.06-8.45$ \\
\hline $\begin{array}{l}\text { Wool preparing and } \\
\text { spinning }\left(17.120^{d}\right)\end{array}$ & 37 & 46 & 1.57 & $0.93-2.64$ \\
\hline Wool weaving (17.220d) & 13 & 38 & 0.58 & $0.29-1.17$ \\
\hline $\begin{array}{l}\text { Wool dyeing and } \\
\text { finishing }\left(17,128^{\circ}\right)\end{array}$ & 2 & 3 & 1.31 & $0.20-8.41$ \\
\hline $\begin{array}{l}\text { Silk preparing and } \\
\text { spinning }\left(17.150^{\mathrm{d}}\right)\end{array}$ & 1 & 3 & 0.79 & $0.08-8.01$ \\
\hline Silk weaving $\left(17.240^{d}\right)$ & 3 & 6 & 0.23 & $0.03-2.09$ \\
\hline
\end{tabular}

a Code of the CNAE-93 in parentheses.

b The reference group comprised those who had never worked in a textile industrial activity.

" Nonconditional logistic regression, adjusted by tobacco consumption, age and gender.

${ }^{a} \mathrm{Ad}$-hoc codes were also used.

e Ad-hoc code.

studies have found an increased risk for cotton textile workers (19) but not for workers dyeing woolen goods (29). It is possible that different substances and exposures in cotton and wool textiles can explain our results. For example, azoic materials, known bladder carcinogens, were mainly used in the dyeing of cotton textiles but not for wools. In addition, in the study by Gonzalez et al (12), small industries in which poor safety measures were common predominated. Conversely, in Vallès Occidental bigger factories predominate, in which more safety measures are expected.

Work conditions have changed across time. The studies published were mostly carried out in the 1970 s or early $1980 \mathrm{~s}$, and, if it is assumed that the mean latency period for bladder cancer is 20 years, cases attributable to occupational risks would have mostly been exposed in the 1950 s and 1960 s at the latest. Since then, work conditions have improved significantly, and in Spain important changes have occurred in the industry from the $1960 \mathrm{~s}$ on, especially after 1975 (28). Our series corresponds to cases that would have been exposed mainly in the 1970s, and the time frame could explain the lack of positive results. Other also recent studies carried out in other 
countries have not found elevated risks for occupations previously associated with bladder cancer (20).

A risk associated with exposure to spinning over a long period of time and during earlier periods was shown by our data, which suggest that exposure changes and improvements in work conditions in general (such as better hygienic standards) could have had an impact on the risk of bladder cancer. Spinners have previously been found to have increased risks of cancers other than those of the bladder (3). Relevant exposure, such as oils and fibers, in contact with the skin or the respiratory tract occurs during spinning, Certain kinds of oils are known to cause cancer in humans (30).

Previous studies have reported an elevated risk for machine operators $(10,18,31)$ because of possible exposure to cutting oils and other substances that contain aromatic amines and nitrosamines (30). We found increased risks for machine setters, especially those exposed from 1960 on. Although machines and ambient air in textile mills are much cleaner now than earlier, the handling of oily materials for machine maintenance has probably not changed much.

The risk of bladder cancer in relation to the age at which exposure began has been a subject of debate. Previous studies found a higher risk for young workers at first employment $(31,32)$, whereas others found a more elevated risk for those older (17). Our series supports the hypothesis that first employment in the textile industry at a younger age tends to involve a more elevated risk.

In conclusion, an overall association between bladder cancer risk and work in the textile industry was not found in our study. Only the subgroup of machine setters exposed in the past and spinning exposed during long periods were significantly associated with a higher risk of bladder cancer.

\section{Acknowledgments}

The study was funded by the Spanish Ministry of Health (Fondo de Investigaciones Sanitarias, 90/0715).

We also want to thank other persons from the urology, records, pathology and oncology departments of all the participating hospitals for their generous contribution to this study. We wish to thank all the people from the municipalities of the county of el Vallès Occidental for their contributions to the selection of the referents, especially to Josep de Andres from Sabadell for his support. We are also grateful to Dr Carlos A Gonzalez (IREC, Mataró, Barcelona) for permitting and facilitating the use and adaptation of the questionnaire for the present study and his suggestions concerning the design phase. To Dr Xavier Bosch (ICO, Barcelona) for his contribution and support during the gestation of the project.

\section{References}

1. Matanoski GM, Elliot EA. Bladder cancer epidemiology. Epidemiol Rev 1981;3:203-29.

2. Waterhouse J, Muir C. Cancer incidence in five continents. Lyon (France): International Agency for Research on Cancer (IARC), 1997. IARC scientific publications no 43, volume V.

3. Alderson M. Occupational cancer. London: Butterworth \& Co, 1986.

4. Silverman DT, Morrison AS, Devesa SS. Bladder cancer. In: Schottenfeld D, Fraumeni J, editors. Cancer epidemiology and prevention. New York (NY): Oxford University Press, 1996.

5. Steineck G, Plato N, Norell SE, Hogstedt C. Urothelial cancer and some industry-related chemicals: an evaluation of the epidemiologic literature. Am J Ind Med 1990;17:371—91.

6. Doll R, Peto R. The causes of cancer: quantitative estimates of avoidable risks of cancer in the United States today. New York(NY): Oxford University Press, 1981.

7. Vineis P, Simonato L. Estimates of the proportion of bladder cancers attributable to occupation. Scand J Work Environ Health 1986;12:55-60.

8. Kogevinas M, Kauppinen T, Boffetta P, Saracci R. Estimation of the burden of occupational cancer in Europe. Barcelona: IMIM, 1998. Final report.

9. Anthony HM, Thomas GM. Tumors of the urinary bladder: an analysis of the occupations of 1,030 patients in Leeds, England. JNCI 1970;45:879-95.

10. Claude JC, Frentzel-Beyme RR, Kunze E. Occupation and risk of cancer of the lower urinary tract among men: a casecontrol study. Int J Cancer 1988;41:371-9.

11. Gonzalez CA, Lopez-Abente G, Errezola M, Castejon J, Estrada A, Garcia-Milan $M$, et al. Occupation, tobacco use, coffee, and bladder cancer in the county of Mataro (Spain). Cancer 1985;55:2031-4.

12. Gonzalez CA, Riboli E, Lopez-Abente G. Bladder cancer among workers in the textile industry: results from a Spanish case-control study. Am J Ind Med 1988;14:673-80.

13. Jensen OM, Wahrendorf J, Knudsen JB, Sørensen BL. The Copenhagen case-referent study on bladder cancer: risks among drivers, painters and certain other occupations. Scand J Work Environ Health 1987;13:129_-34.

14. La Vecchia C, Negri E, D’Avanzo B, Franceschi S. Occupation and risk of bladder cancer. Int J Epidemiol 1990;19:26468.

15. Steenland K, Burnett C, Osorio AM. A case-control study of bladder cancer using city directories as source of occupational data. Am J Epidemiol 1987;126:247-57.

16. Hueper WC, Wiley FH, Wolfe HD. Experimental production of bladder tumours in dogs by administration of beta-naphthylamine. J Ind Hyg Toxicol 1938;20:46-84.

17. Case RAM, Hosker ME, McDonald DB, Pearson JT. Tumours of the urinary bladder in workmen engaged in the manufacture and use of certain dyestuff intermediates in the British Chemical Industry, part I: the role of aniline, benzidine, alpha-naphthylamine, and beta-naphthylamine. Br J Ind Med 1954;11:75-104.

18. Gonzalez CA, Lopez-Abente G, Errezola M, Escolar A, Riboli E, Izarzugaza I, et al. Occupation and bladder cancer in Spain: a multi-centre case-control study. Int J Epidemiol 1989;18:569-77.

19. Henderson V, Enterline PE. An unusual mortality experience in cotton textile workers. J Occup Med 1973;15:717-9. 
20. Cordier S, Clavel J, Limasset JC, Boccon-Gibod L, Le Moual $\mathrm{N}$, Mandereau L, et al. Occupational risks of bladder cancer in France: a multicentre case-control study. Int J Epidemiol 1993;22:403-11.

21. Kunze E, Chang-Claude J, Frentzel-Beyme R. Life style and occupational risk factors for bladder cancer in Germany: a case-control study. Cancer 1992;69:1776-89.

22. Gomez C, Ladero JM, Tapia D, Muñoz JJ, Gonzalez F. Urothelioma of the bladder: case-control study in Madrid area. Rev Clin Esp 1987;180:352-6.

23. International Agency for Research on Cancer (IARC). Some retardants flame retardants and textile chemicals, and exposures in the textile manufacturing industry. Lyon: IARC, 1990. IARC monographs on the evaluation of carcinogenic risks to humans, volume 48 .

24. Lopez-Abente G. Bladder cancer in Spain:mortality trends (1955-75). Cancer 1983;51:2367-70.

25. Gil A, Alfonso JL, Cortes C, Saiz C, Cortina P. Cancer de vejiga: estudio de la mortalidad en España (1968-1982). Actas Urol Esp 1989;13:85-9.

26. Urrútia G, Serra C, Bonfill X, Bastús R. Incidencia del cáncer de vejiga en una área de Cataluña y su comparación con otras áreas españolas y europeas [Incidence of bladder cancer in an area of Catalonia and its comparison with other Spanish and European areas]. Gac Sanit 1998;12 suppl 2:25.

27. Gonzalez CA, Lopez-Abente G, Errezola M, Escolar A, Izarzugaza I, Riboli E, et al. Diseño y realización de un estudio multicéntrico caso-control sobre cáncer de vejiga en España. Med Clin (Barc) 1989;92:646-51.

28. Fabregat V. Tèxtil i confecció. Barcelona: Departament d'Industria, 1992. La industria a Catalunya, no 9.

29. Cartwright R. Occupational bladder cancer and cigarette smoking in West Yorkshire. Scand J Work Environ Health 1982;8 suppl 1:79-82.

30. International Agency for Research on Cancer (IARC). Polynuclear aromatic compounds, part 2. Lyon: IARC, 1984. IARC monographs on the evaluation of carcinogenic risks to humans, no 33.

31. Cole P, Hoover R, Friedell GH. Occupation and cancer of the lower urinary tract. Cancer 1972;29:1250-60.

32. Hoover $\mathrm{R}$, Cole P. Temporal aspects of occupational bladder carcinogenesis. N Engl J Med 1973;288:1040-3.

Received for publication: 18 January 2000 